\title{
Characterization of a Bacteriocin Produced by Enterococcus gallinarum CRL 1826 Isolated from Captive Bullfrog: Evaluation of its Mode of Action against Listeria monocytogenes and Gram-Negatives
}

\section{Montel Mendoza G' ${ }^{1}$ Ale CE¹, Nader-Macías MEF² and Pasteris SE$^{1 *}$}

${ }^{1}$ Instituto Superior de Investigaciones Biológicas (INSIBIO), CONICET-UNT, and Instituto de Biología "Dr. Francisco D. Barbieri", Facultad de Bioquímica, Química y Farmacia, UNT. Chacabuco 461, T4000ILI - San Miguel de Tucumán, Argentina

${ }^{2}$ Centro de Referencia para Lactobacilos (CERELA-CONICET). Chacabuco 145, T4000ILC - San Miguel de Tucumán, Argentina

\begin{abstract}
Enterococcus gallinarum CRL 1826 isolated from an American bullfrog (Lithobates catesbeianus) skin inhibits the growth of Citrobacter freundii, Pseudomonas aeruginosa (bullfrog pathogens) and Listeria monocytogenes by a synergistic effect between organic acids and a bacteriocin-like molecule. This bacteriocin, named enterocin CRL 1826, showed a proteinaceous nature, heat stability and polar characteristics. Its production followed kinetics of primary metabolites synthesis reaching a maximum of $61,400 \mathrm{AU} / \mathrm{mL}$. The minimum inhibitory and minimum bactericidal concentrations were 2,640 and $5,280 \mathrm{AU} / \mathrm{mL}$, respectively, against $L$. monocytogenes. The addition of $120,000 \mathrm{AU} / \mathrm{mL}$ of enterocin to growing $L$. monocytogenes and Gram-negative $(P$. aeruginosa and $C$. freundii) bacteria showed bactericidal and bacteriostatic effects, respectively. However, enterocin derived-peptides had bactericidal effect only against Gram-negatives.

Enterocin produced cell envelope damages and efflux of citosolic content on $L$. monocytogenes, while enterocin derived-peptides showed granulation and contraction of cytoplasm material on $P$. aeruginosa and increase in the periplasmic space and empty cells appearance on $C$. freundii.

Enterocin CRL 1826 is the first bacteriocin described for $E$. gallinarum from raniculture. It could be used as a biopreservative while the derived-peptides represent an alternative to control multi-drug resistant Gram-negatives. The antimicrobial spectrum and the stability of enterocin and its derived-peptides indicate that they could be applied in different biotechnological areas.
\end{abstract}

Keywords: Enterococcus gallinarum; Raniculture; Bacteriocin; Probiotics; Biopreservatives

\section{Introduction}

Lactic Acid Bacteria (LAB) isolated from aquatic environments produce a range of antagonistic molecules such as organic acids, hydrogen peroxide, diacetyl, and bacteriocins [1]. The characterization of these compounds supports the selection of beneficial LAB. Thus, some species have been proposed as probiotics to restore beneficial microbial populations that could help to control potentially pathogenic microorganisms in general aquaculture [2,3] and raniculture [4-6].

Probiotic products are generally designed with single or mixed beneficial bacterial strains, mainly LAB, but they could also include different bioactive compounds such as prebiotics (inulin) or bacteriocins [7]. Postbiotic metabolites (lactic and acetic acids and bacteriocins) produced by LAB strains have been extensively studied as feed additive to achieve high productivity and better laying hens' health while reducing in-feed antibiotics [8].

Bacteriocins are ribosomally-synthesized antimicrobial peptides or proteins produced by different bacterial genera. They are usually active against genetically close species and have been grouped into four classes according to their genetic and biochemical characteristics and mode of action [9]. In recent years, bacteriocins have attracted increasing interest for their use as biopreservatives in food industry, Nisin and Pediocin PA, being commercially available as Nisaplin and ALTA 2341, respectively. They are used as food additives [10] according to their GRAS (Generally Regarded as Safe) characteristics [11-13]. More recently, the effectiveness of Nisin A to reduce spoilage bacteria in high-fat chilled dairy dessert, a milk-based pudding, was reported [14].

Listeria is a ubiquitous bacterium extremely dangerous for high risk human populations. Listeria monocytogenes is the most pathogenic species associated with aquaculture products such as raw, smoked and fermented fish and crab meat $[15,16]$. It is a frequent inhabitant isolated from different frog species including the American bullfrog (Lithobates catesbeianus) [17] which meat is considered a delicacy in the international gastronomy. Thus, this pathogenic microorganism could be transferred as food-borne bacteria during bullfrogs' meat manufacturing.

Enterocins are bacteriocins produced by Enterococcus species that are able to inhibit Gram-positives such as L. monocytogenes [18-23] and some Gram-negatives in a lesser degree [24-26].

In previous studies, we demonstrated that Gram-negative bacteria are responsible for Red-Leg Syndrome (RLS) outbreaks in raniculture: Also, enterococci were isolated from the autochthonous microbiota

${ }^{*}$ Corresponding author: Sergio E Pasteris, Instituto Superior de Investigaciones Biológicas (INSIBIO), CONICET-UNT, and Instituto de Biología "Dr. Francisco D. Barbieri", Facultad de Bioquímica, Química y Farmacia, UNT, San Migue de Tucumán, Argentina, Tel: +543814247752; Ext: 7093; Fax: +543814310465 E-mail: pasteris@fbqf.unt.edu.ar

Received August 06, 2015; Accepted August 18, 2015; Published August 24 2015

Citation: Montel Mendoza G, Ale CE, Nader-Macías MEF, Pasteris SE (2015) Characterization of a Bacteriocin Produced by Enterococcus gallinarum CRL 1826 Isolated from Captive Bullfrog: Evaluation of its Mode of Action against Listeria monocytogenes and Gram-Negatives. J Bioprocess Biotech 5: 250 doi:10.4172/2155-9821.1000250

Copyright: (c) 2015 Montel Mendoza G, et al. This is an open-access article distributed under the terms of the Creative Commons Attribution License, which permits unrestricted use, distribution, and reproduction in any medium, provided the original author and source are credited. 
Citation: Montel Mendoza G, Ale CE, Nader-Macías MEF, Pasteris SE (2015) Characterization of a Bacteriocin Produced by Enterococcus gallinarum CRL 1826 Isolated from Captive Bullfrog: Evaluation of its Mode of Action against Listeria monocytogenes and Gram-Negatives. J Bioprocess Biotech 5: 250 doi:10.4172/2155-9821.1000250

associated with L. catesbeianus hatchery environments [4,6,27]. Enterococcus gallinarum CRL 1826 isolated from the bullfrog skin inhibited the growth of L. monocygenes Scott A by a synergistic effect among lactic acid, hydrogen peroxide and a bacteriocin-like metabolite [6]. Preliminary studies have indicated that bacteriocin containing culture supernatants treated with proteolytic enzymes inhibited the growth of RLS-related pathogens (Pseudomonas aeruginosa and Citrobacter freundii). Taking into account that enteroccoci are considered no GRAS species [28,29], E. gallinarum CRL 1826 cannot be included in probiotics for raniculture. However, the natural products (bacteriocin/s) could be used as biopreservative to reduce $L$. monocytogenes prevalence or as a bioactive ingredient for probiotics formulation.

Thus, the present study aimed to characterize the bacteriocin from E. gallinarum CRL 1826 culture supernatants and to evaluate its mode of action against a food-borne bacterium (L. monocytogenes) and indigenous RLS-related pathogens, as a potential bioactive agent to be included as biopreservative during the manufacture of bullfrog carcasses and probiotics' formulation, respectively.

\section{Materials and Methods}

\section{Bacterial strains and culture conditions}

Enterococcus gallinarum CRL 1826 was isolated from the ventral skin of healthy L. catesbeianus and identified by phenotypic and genotypic tests [6]. The strain was grown on MRS broth [30], LAPT g broth [31] pH 6.8 and Brain Heart Infusion (BHI) broth pH 7.4, for 10 $\mathrm{h}$ at $37^{\circ} \mathrm{C}$ in a $5 \% \mathrm{CO}_{2}$-enriched chamber (microaerophilic conditions).

Pseudomonas aeruginosa 1047 and Citrobacter freundii $\mathrm{CFb}$ isolated from raniculture were grown in nutritive broth (in $\mathrm{g} / \mathrm{L}$ : pluripeptone, 5; meat extract, 3), $\mathrm{pH} 6.9$ for $7 \mathrm{~h}$ while Listeria monocytogenes Scott A was cultured in BHI broth, for $6 \mathrm{~h}$. All cultures were incubated at $37^{\circ} \mathrm{C}$ in microaerophilic conditions $[6,32]$. Bacterial strains were stored at $-20^{\circ} \mathrm{C}$ in their specific growth media supplemented with $20 \%(\mathrm{w} / \mathrm{v})$ glycerol.

\section{Characterization of the bacteriocin produced by Enterococcus gallinarum CRL 1826}

One-hundred milliliters of $10 \mathrm{~h}$ cultures of E. gallinarum CRL 1826 grown in MRS, LAPTg and BHI broth were centrifuged $\left(3,000 \mathrm{~g}\right.$ at $4^{\circ} \mathrm{C}$, $20 \mathrm{~min}$ ) and $3 \mathrm{~mL}$ fractions of crude (untreated), neutralized (NS) and neutralized+catalase (treated) supernatants were used to determine the chemical nature of the bacteriocin-like metabolite. Its activity was evaluated by the agar-well diffusion assay according to Pasteris et al. [4]. Thus, soft BHI agar $(0.7 \% \mathrm{w} / \mathrm{v})$ plates were inoculated with $1 \times$ $10^{5} \mathrm{CFU} / \mathrm{mL}$ L. monocytogenes. Then, $100 \mu \mathrm{L}$ of untreated, NS, and treated supernatants were added to the plates in which $10 \mathrm{~mm}$ holes had been previously punched. Fractions of crude supernatants were formerly adjusted to $\mathrm{pH} 7.0$ with $1 \mathrm{~N} \mathrm{NaOH}$ (NS) and NS samples were supplemented with $0.5 \mathrm{mg} / \mathrm{mL}$ catalase $\left(1 \mathrm{~h}\right.$ at $\left.25^{\circ} \mathrm{C}\right)$ to abolish the inhibitory effect due to organic acids and $\mathrm{H}_{2} \mathrm{O}_{2}$, respectively [4].

The antimicrobial titer was defined as the reciprocal of the highest two fold dilution able to produce a clear zone of inhibition and was expressed as arbitrary units per milliliter of culture supernatant $(\mathrm{AU} / \mathrm{mL})$.

\section{Chemical nature of the bacteriocin}

Two-milliliter fractions of treated supernatants from MRS cultures were supplemented with $1 \mathrm{mg} / \mathrm{mL}$ pepsin, $\alpha$-chymotrypsin, trypsin, lipase and $\alpha$-amylase. Enzymes were suspended in their specific buffer solutions according to the suppliers' indications [32]. Positive and negative controls were performed with enzyme solutions and treated fractions diluted with sterile water, respectively. Enzymatic treatments of cell-free supernatants were carried out for $1 \mathrm{~h}$ at $37^{\circ} \mathrm{C}$ except for a-chymotrypsin that were incubated for $1 \mathrm{~h}$ at $25^{\circ} \mathrm{C}$ [32].

\section{Physicochemical characterization of the bacteriocin produced by the lactic acid bacterium}

Effect of organic solvents and filtration on bacteriocin activity: Five-milliliter fractions of untreated and treated supernatant were supplemented with different organic solvents: 10 and $20 \%(\mathrm{v} / \mathrm{v})$ hexadecane, ethyl acetate, chloroform and ethanol $[4,5]$.

Moreover, 2-mL fractions of untreated and treated supernatants were filtered throughout $0.22 \mu \mathrm{m}$ Millipore membranes (SigmaAldrich). The collected untreated samples were neutralized with $1 \mathrm{~N}$ $\mathrm{NaOH}$ before the quantification of bactericion activity [32].

Temperature stability of the bacteriocin: Five-milliliter fractions of untreated and treated supernatants were exposed to 60,80 and $100^{\circ} \mathrm{C}$ for 10,20 and $30 \mathrm{~min}$ and to $121^{\circ} \mathrm{C}$ (autoclave) for 1, 5, 10, 15 and 30 min previous to residual bacteriocin activity determination. Samples without treatment were used as control.

\section{Growth of Enterococcus gallinarum CRL 1826 and kinetics of the bacteriocin production}

Growth of the LAB strain was evaluated in MRS broth for $34 \mathrm{~h}$ in the conditions stated above. Samples were taken at different time intervals for growth determinations [optical density $\lambda=540 \mathrm{~nm}$ and number of colony-forming units $(\mathrm{CFU} / \mathrm{mL})]$. Cultures were centrifuged $(3,000$ $g$ at $4^{\circ} \mathrm{C}, 15 \mathrm{~min}$ ) to obtain crude supernatants which were used for $\mathrm{pH}$ determinations [4-6]. Treated supernatants were then used for bacteriocin quantification against L. monocytogenes [32].

\section{Storage conditions: effect of $\mathrm{pH}$ and temperature on bacteriocin stability}

To study the stability of the bacteriocin during storage, untreated and treated cell-free supernatants fractions were kept at $-20^{\circ} \mathrm{C}$ and the residual bacteriocin activity was determined up to 42 days.

The combined effect of $\mathrm{pH}$ and temperature on the bacteriocin stability during storage was evaluated. Thus, $30-\mathrm{mL}$ fractions of the LAB strain supernatants containing bacteriocin were heated at $80^{\circ} \mathrm{C}$ for 30 min adjusted to $\mathrm{pH}$ values between 2 and 9 by using sterilized $1 \mathrm{~N}$ $\mathrm{HCl}$ and $\mathrm{NaOH}$ solutions and kept at 4 and $25^{\circ} \mathrm{C}$ for 7 days. Every day samples were removed, neutralized and treated with catalase previous to bacteriocin quantification [32].

\section{Minimum inhibitory concentration (MIC) and minimum bactericidal concentration (MBC) of the bacteriocin}

Culture supernatants of E. gallinarum CRL 1826 were obtained according to the protocol described above, concentrated 10 times in a SAVANT (SpeedVac Concentrators), and filtered throughout $0.22 \mu \mathrm{m}$ Millipore membranes. Sterilized supernatants were adjusted to $\mathrm{pH} 7.0$ with $5 \mathrm{~N} \mathrm{NaOH}$ and the bacteriocin quantification was carried out by using L. monocytogenes as indicator strain [32].

The MIC of the bacteriocin was determined by the method of dilution in BHI broth following the guidelines of the Clinical Laboratory Standard Institute (CLSI) [33], while the MBC was determined according to the CLSI [34] recommendations. 
Citation: Montel Mendoza G, Ale CE, Nader-Macías MEF, Pasteris SE (2015) Characterization of a Bacteriocin Produced by Enterococcus gallinarum CRL 1826 Isolated from Captive Bullfrog: Evaluation of its Mode of Action against Listeria monocytogenes and Gram-Negatives. J Bioprocess Biotech 5: 250 doi:10.4172/2155-9821.1000250

Page 3 of 9

\section{Mode of action of the bacteriocin on pathogen cells}

The effect of the bacteriocin on indigenous RLS-related pathogens (C. freundii and P. aeruginosa) and L. monocytogenes was evaluated following the guidelines of the CLSI [34]. Thus, 200-mL LAB cultures $\left(6 \mathrm{~h}\right.$ at $\left.37^{\circ} \mathrm{C}\right)$ were harvested; cells were washed twice with sterile Phosphate-Buffered Saline (PBS, pH 7.0) and suspended in order to get approximately $1 \times 10^{8} \mathrm{CFU} / \mathrm{mL}$. Concentrated supernatants were obtained as indicated above and $4.75 \mathrm{~mL}$ of a-treated supernatant and b-treated supernatant + trypsin were supplemented with $0.2 \mathrm{~mL} \mathrm{BHI}$ broth to reach the nutritional conditions suitable for pathogens growth and then inoculated with the pathogen cell suspensions to obtain 5 $\times 10^{6} \mathrm{CFU} / \mathrm{mL}$. The bacteriocin concentration in each treatment was $120,000 \mathrm{AU} / \mathrm{mL}$.

Treated supernatant + trypsin were heated at $121^{\circ} \mathrm{C}$ for $10 \mathrm{~min}$ to abolish the enzyme activity on bacterial cell wall components.

All the samples were incubated at $37^{\circ} \mathrm{C}$ in microaerophilic conditions and the number of viable cells $(\mathrm{CFU} / \mathrm{mL})$ was determined every hour during $6 \mathrm{~h}$. The ultrastructural cell damages were analyzed in L. monocytogenes cells treated with bacteriocin for $30 \mathrm{~min}$ and on RLS-related pathogens treated with bacteriocin derived-peptide: $1.5 \mathrm{~h}$ for $P$. aeruginosa and $2.5 \mathrm{~h}$ for $C$. freundii.

\section{Transmission electron microscopy (TEM)}

Pathogenic cells obtained under each of the experimental conditions described above were harvested, suspended in MRS medium supplemented with $3 \%$ glutaraldehyde $(1: 1 \mathrm{v} / \mathrm{v})$ and incubated for $30 \mathrm{~min}$ at room temperature; then they were centrifuged at 3,000 $g$ at $4^{\circ} \mathrm{C}$ for $5 \mathrm{~min}$ and suspended in $3 \%$ glutaraldehyde. Finally, cells were processed and observed by TEM [35].

Chemicals, Millipore membranes and enzymes used were purchased from Sigma-Aldrich Chemical Co., St. Louis, MO (USA). The components for LAPTg preparation were supplied by Britania laboratories (Buenos Aires, Argentina) while MRS and BHI media were obtained from Merck (Germany).

\section{Statistical analysis}

The results correspond to the media of three independent assays. Statistical treatments were performed using INFOSTAT software (2008 student version). For bacteriocin thermal sensitivity assays, oneway analysis of variance (ANOVA) was applied to the experimental data by using Student's $t$-test for multiple mean comparisons $(95 \%$ confidence interval). The significant differences among the residual bacteriocin activity under storage conditions were determined by applying the non-parametric analysis of variance (Kruskal Wallis test, $95 \%$ confidence interval).

\section{Results}

\section{Chemical nature and thermal stability of the bacteriocin produced by Enterococcus gallinarum CRL 1826}

The antimicrobial activity of treated (neutralized + catalase) supernatants from the E. gallinarum strain cultures was abolished when fractions were subjected to the action of pepsine, chymotripsin and trypsin, indicating that the inhibitory metabolite has a proteinaceus nature. Amylase and lipase did not affect the bacteriocin activity (Table 1). Thus, the bacteriocin was named enterocin CRL 1826. The LAB strain was able to produce enterocin in all the media assayed in this work: MRS, LAPTg and BHI broth. The highest inhibitory activity values were detected in MRS (data no shown), then, samples from MRS cultures were used for the bacteriocin characterization. Therefore, the effect of some physicochemical factors on enterocin stability was evaluated. No differences in the activity were detected when organic solvents were added to both untreated and treated culture supernatants. Their supplementation with 10 and $20 \%(\mathrm{v} / \mathrm{v})$ hexadecane did not modify the bacteriocin activity, while the addition of 10 and $20 \%(\mathrm{v} / \mathrm{v})$ ethyl acetate decreased it by $25 \%$; and 10 and $20 \%(\mathrm{v} / \mathrm{v})$ chloroform by 45 and $69 \%$, respectively. Also, ethanol inhibited the enterocin activity by $78 \%$ (Table 1). Filtration did not affect enterocin activity, independently of the supernatant fraction evaluated.

The effect of heating on enterocin CRL 1826 stability was determined and no significant differences $(P>0.05)$ between treated and untreated supernatants were observed (Figure 1A). The antimicrobial molecule was stable up to $80^{\circ} \mathrm{C}$ for $30 \mathrm{~min}$ as its residual activity did not differ significantly from the control $(P>0.05)$. At $100^{\circ} \mathrm{C}$ a significant diminution $(59 \pm 13 \%)$ in the inhibitory activity was observed (Figure 1B). Moreover, at $121^{\circ} \mathrm{C}$ the loss of the enterocin activity was significantly affected $(P \leq 0.05)$ and depended on $\mathrm{pH}$ values. After 15 min treatment, 50 and $20 \%$ residual activity were detected in untreated and treated supernatants, respectively (Figure 1B).

\section{Growth and kinetics of the enterocin production by Enterococcus gallinarum CRL 1826}

The growth of E. gallinarum CRL 1826 in MRS broth under microaerophilic conditions and the enterocin production using $L$. monocytogenes as indicator strain are shown in Figure 2. After $4 \mathrm{~h}$, the LAB strain grew exponentially during $6 \mathrm{~h}$, while the number of viable cells increased $2.5 \log _{10}$ units and the $\mathrm{pH}$ decreased about 1.0 unit at $10 \mathrm{~h}$ culture. The enterocin synthesis started at the beginning of the exponential growth phase $(40 \mathrm{AU} / \mathrm{mL})$, reaching a maximum of 61,440 $\mathrm{AU} / \mathrm{mL}$ at the end of this phase $(6 \mathrm{~h})$. Then, enterocin activity remained stable until $16 \mathrm{~h}$ culture; however, at $22 \mathrm{~h}$ it diminished up to 25,600 $\mathrm{AU} / \mathrm{mL}$, title that was kept until the end of the assay (34 h) (Figure 2).

\section{Effect of $\mathrm{pH}$ and temperature of storage on enterocin stability}

No inactivation of the enterocin CRL 1826 was observed when untreated and treated supernatants of the LAB strain were stored at $-20^{\circ} \mathrm{C}$ for 42 days (data not shown).

When crude supernatants were adjusted to $\mathrm{pH}$ between 2 and 9 and stored at 4 and $25^{\circ} \mathrm{C}$ for 7 days, the $\mathrm{pH}$ did not exert significant effect $(P>0.05)$ on the residual enterocin activity (Figure $3 \mathrm{~A})$. On the other hand, a significant decrease $(P \leq 0.05)$ in bacteriocin activity was observed during the storage of untreated and treated supernatants,

\begin{tabular}{|c|c|}
\hline Supernatant & Residual activity (\%) $^{*}$ \\
\hline Neutralized + catalase $(\mathrm{N}+\mathrm{C})$ & $100^{* *}$ \\
\hline $\mathrm{N}+\mathrm{C}+$ pepsin & 0 \\
\hline $\mathrm{N}+\mathrm{C}+$ trypsin & 0 \\
\hline $\mathrm{N}+\mathrm{C}+\alpha$-chymotrypsin & 100 \\
\hline $\mathrm{N}+\mathrm{C}+$ lipase & 100 \\
\hline $\mathrm{N}+\mathrm{C}+$-amylase & 100 \\
\hline 10 and $20 \%$ hexadecane & 75 \\
\hline 10 and $20 \%$ ethyl acetate & 55 \\
\hline $10 \%$ chloroform & 31 \\
\hline $20 \%$ chloroform & 22 \\
\hline 10 and $20 \%$ ethanol & 0 \\
\hline
\end{tabular}

Table 1: Effect of chemical treatments on bacteriocin activity; *Percentage of the inhibitory activity on $L$. monocytogenes growth; ${ }^{* *} 100 \%=61,440 \mathrm{AU} / \mathrm{mL}$ (control). 
a)

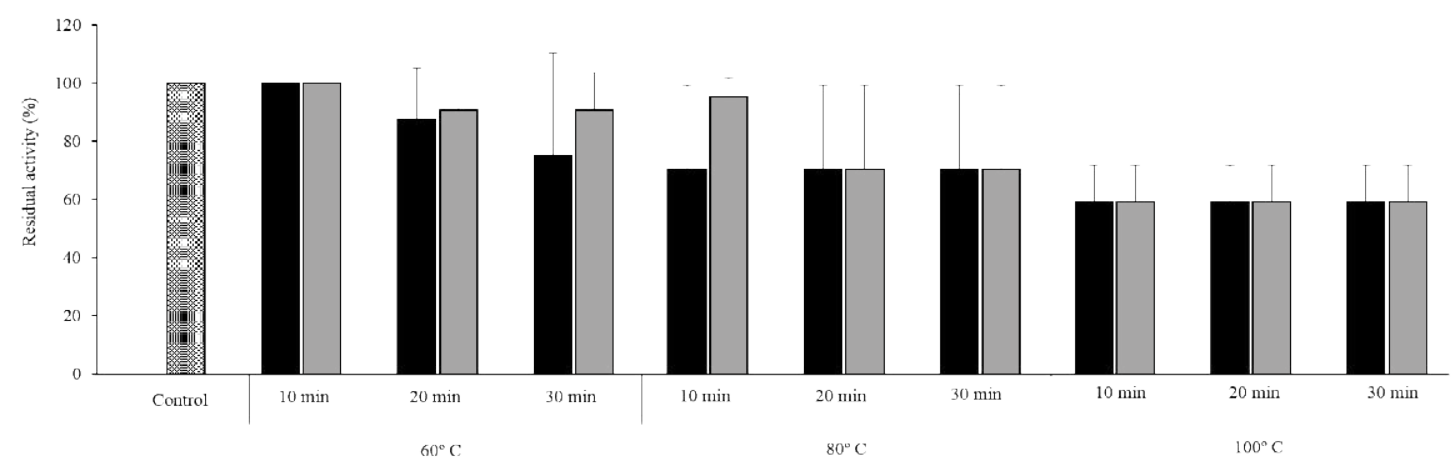

b)

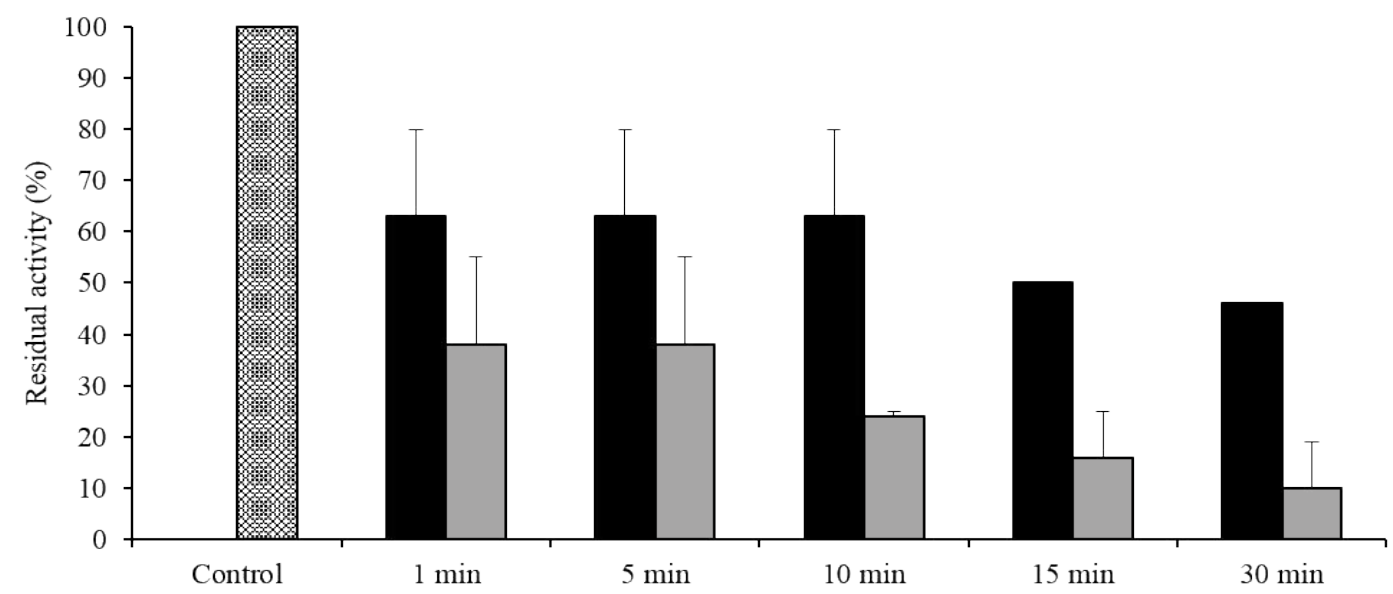

Figure 1: Effect of temperature and time on enterocin CRL 1826 activity (a) 60,80 and $100^{\circ} \mathrm{C}$ for 10,20 and 30 min (b) $121^{\circ} \mathrm{C}$ for $1,5,10,15$ and 30 min. Results are expressed as $\%$ of residual activity $(100 \%=61,440 \mathrm{AU} / \mathrm{mL})$. Black bars: crude supernatants; gray bars: neutralized supernatants.

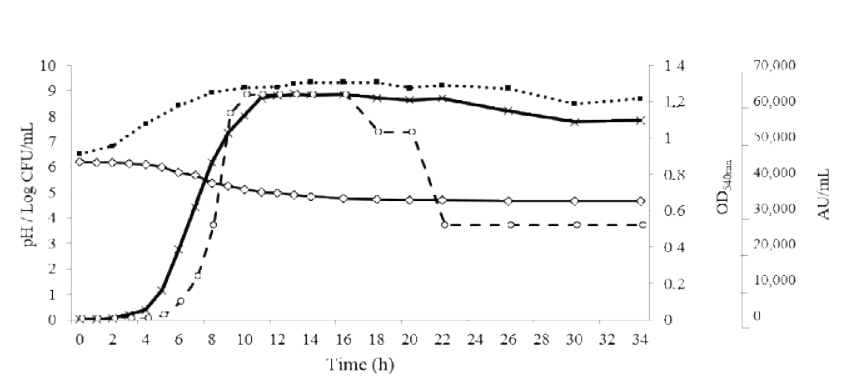

Figure 2: Growth and bacteriocin production by Enterococcus gallinarum CRL 1826

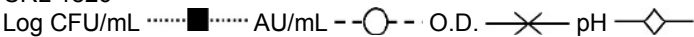

indicated by the factor time according to the Kruskal Wallis analysis (Figure 3A)

Although the statistical analysis of the data did not show significant differences between both temperatures of storage, a dissimilar profile in the mean values of the residual enterocin activity was observed when supernatants were stored at 4 and $25^{\circ} \mathrm{C}$ (Figure 3B and 3C). Therefore, at $4^{\circ} \mathrm{C}$ the highest enterocin activity was detected at $\mathrm{pH} 4$ and 5 , while at $25^{\circ} \mathrm{C}$ the highest activity was obtained when supernatants were stored at neutral $\mathrm{pH}(6.5 \pm 0.5)$.

\section{MIC, MBC, mode of action of the enterocin on pathogenic bacteria and studies of cell damage}

The MIC of enterocin CRL 1826 against L. monocytogenes was 2,640 AU/mL while the MBC resulted in 5,280 AU/mL. The effect of the addition of 120,000 AU/mL enterocin on L. monocytogenes, $C$. freundii and $P$. aeruginos a cells was studied. Therefore, neutralized supernatants exerted a bactericidal effect on $L$. monocytogenes and no viable cells were detected at $60 \mathrm{~min}$ co-incubation (Figure 4). However, when samples of treated supernatants were supplemented with trypsin before its addition to pathogenic cells, a bacteriostatic effect was observed. The same effect was also detected for $C$. freundii and $P$. aeruginosa when cells were co-incubated with neutralized supernatants (data not shown). When these supernatants were then treated with trypsin, a bactericidal effect was observed and no cell counts were detected at 2 and $3 \mathrm{~h}$ incubation for P. aeruginosa and C. freundii, respectively.

When analyzing the control samples, L. monocytogenes grew poorly ( $0.22 \log$ units) while $P$. aeruginosa and and $C$. freundii grew to 0.46 and $0.59 \log$ units, respectively.

Ultrastructural studies in $L$. monocytogenes cells treated with bacteriocin and both $P$. aeruginosa and $C$. freundii treated with bacteriocin derived-peptides were performed. Listeria revealed that the predominant features of morphological alterations concern the partial 
A

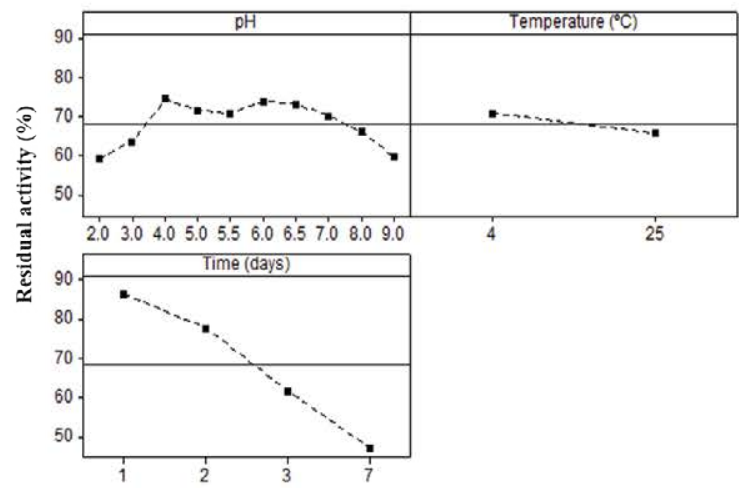

B

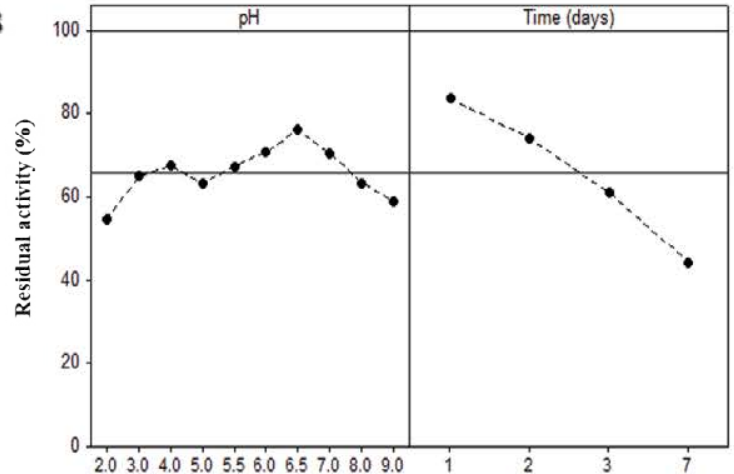

C

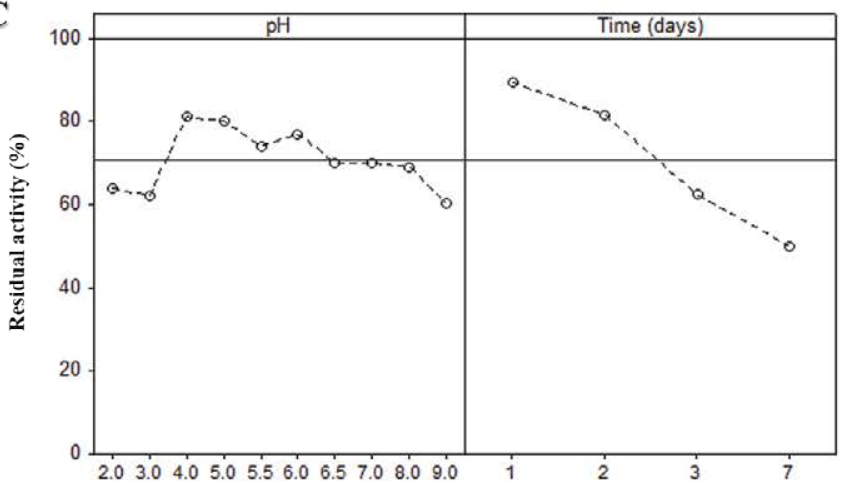

Figure 3: Main effects of $\mathrm{pH}$, temperature and time on enterocin $\mathrm{CRL} 1826$ stability during storage (a) Global position; (b) $4^{\circ} \mathrm{C}$; (c) $25^{\circ} \mathrm{C}$. Similar letters indicates no significant differences $(P \leq 0.05)$ by using Kruskal Wallis test between initial and final points.

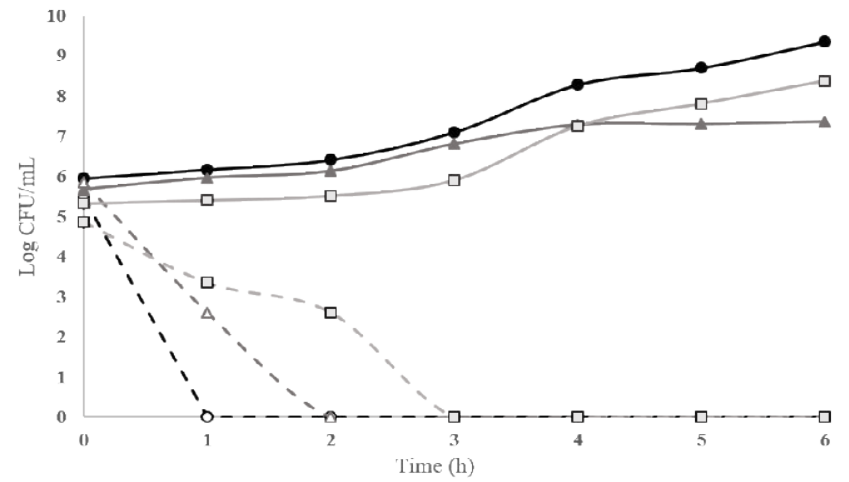

Figure 4: Growth inhibition of pathogenic bacteria by both enterocin and enterocin-derived peptides fractions

L. monocytogenes control (-) and neutralized supernatant + catalase $(-\infty--)$

$P$. aeruginosa control $(-\infty)$ and neutralized supernatant + catalase + tripsine $(---1-)$

C. freundii control $(-\square-$ ) and neutralized supernatant + catalase + tripsine $(--\square-)$

Samples containing enzymes were treated at $121^{\circ} \mathrm{C}, 3$ min before dead curves performance.

dissolution of the cell content (diminution in the cytosolic electron density) and damage of the cell envelope which enabled an efflux of cell material (Figure 5A and 5B). Pseudomonas showed both granulation and contraction of cytoplasm material (Figure 5C and 5D) while Citrobacter showed an increase in the periplasmic space and empty cells appearance (Figure 5E and 5F).

\section{Discussion}

Enterocins are antimicrobial substances with a potential use as biopreservatives in food, feed, and also as alternative therapies instead of antibiotics for human and animals [36]. Some enterocins were reported to be active against $L$. monocytogenes and their potential antilisterial activity was also shown in a murine model of pregnancyassociated listeriosis [37]. Moreover, few enterocins have been found to be effective against Gram-negatives, an unusual characteristic among bacteriocins from LAB species $[24,25]$.

E. gallinarum CRL 1826 is an autochthonous LAB strain isolated from bullfrog skin in hatchery conditions [6]. The synergistic effect of a bacteriocin-like molecule, hydrogen peroxide and organic acids against $L$. monocytogenes Scott A was previously demonstrated [6] and preliminary studies showed that bacteriocin derived-peptides were effective against $C$. freundii and $P$. aeruginosa (RLS-related pathogens for raniculture). On the basis of these observations, the aim of this work was to go further on the characterization of the bacteriocin produced by E. gallinarum CRL 1826 from cell-free supernatants, supported by their potential biotechnological applications. The results indicate that the inhibitory molecule has a proteinaceus nature and therefore it was named enterocin CRL 1826.

Most of the enterocins have been reported to be produced by E. faecium and E. faecalis strains [26,38,39], although some bacteriocinogenic E. mundtii [40-42], E. casseliflavus [43], E. hirae [44], E. avium [45] and E. durans [23] strains were described. With respect to E. gallinarum strains, Jennes et al. [46] characterized for the first time the enterocin 012 produced by E. gallinarum 012 isolated from the intestinal tract of ostrich. To our knowledge, there are no reports on bacteriocins produced by this LAB species isolated from 
Citation: Montel Mendoza G, Ale CE, Nader-Macías MEF, Pasteris SE (2015) Characterization of a Bacteriocin Produced by Enterococcus gallinarum CRL 1826 Isolated from Captive Bullfrog: Evaluation of its Mode of Action against Listeria monocytogenes and Gram-Negatives. J Bioprocess Biotech 5: 250 doi:10.4172/2155-9821.1000250
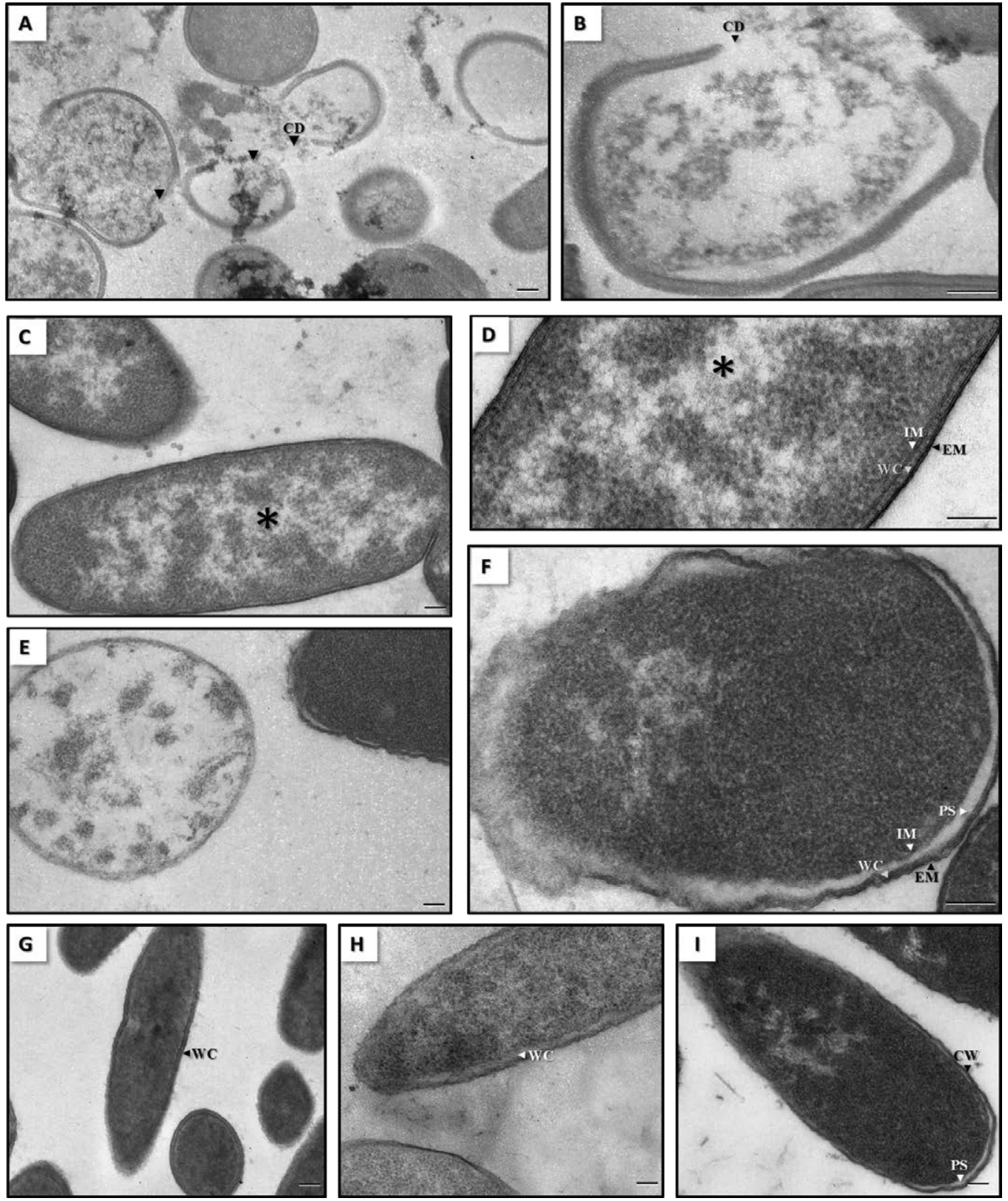

Figure 5: Transmission electronic microscopy of pathogens incubated with enterocin and enterocin-derived peptides fractions. $L$. monocytogenes treatment: A22,800X, B- 56,600X, control: G- 22,800X. P. aeruginosa treatment: C- 22,800X, D- 56,600X, control: H- 22,800X. C. freundii treatment: E- 22,800X, F- 56,600X, control: I- 22,800X. IM: Internal Membrane; EM: External Membrane; WC: Wall Cell; PS: Periplasmic Space; CD: Cellular Disruption. 'Diminution of electron density. Scale bar: $200 \mathrm{~nm}$.

aquaculture-related activities, thus enterocin CRL 1826 represents the first bacteriocin produced by E. gallinarum CRL 1826 isolated from captive bullfrogs.

Enterocin CRL 1826 inhibited the growth of Lactobacillus plantarum, Pediococcus pentosaceus, Lactococcus lactis and L. garvieae strains isolated from a bullfrog hatchery (data no shown) as well as L. monocytogenes Scott A. Overall, bacteriocins produced by LAB are effective against closely related Gram-positives species [9] and most of the enterocins are able to inhibit the Listeria species growth since they are phylogenetically associated with the genus Enterococcus. However, enterocin's inhibition on P. aeruginosa, P. putida, Salmonella spp.,
Salmonella Typhimurium, Escherichia coli, Acinetobacter baumanii, Klebsiella pneumoniae, Proteus spp., P. mirabilis, Citrobacter spp., Enterobacter spp., Vibrio spp., Shigella spp., was also reported [26,46-50].

Enterocin CRL 1826 showed kinetics of primary metabolites synthesis since its production started at the beginning of the log growth phase, reaching a maximum of $61,400 \mathrm{AU} / \mathrm{mL}$ at the end of this phase. Then, the bacteriocin activity decreased. This diminution can be attributed to the presence of proteolytic enzymes in the culture supernatants or to the low $\mathrm{pH}$ values that allows the bacteriocin to be absorbed to the bacterial wall cell [51]. Similar results were reported for the enterocins produced by E. mundtii [42] and E. faecium [52,53]. 
However, Jennes et al. [46] reported a different behavior for the enterocin 012 synthesis that started in the middle log phase, reaching a first maximum at the end of this phase and a second one with the highest enterocin activity during the stationary growth phase.

Enterocin CRL 1826 was heat stable and polar. Its inhibitory activity was preserved in a $\mathrm{pH}$ range between 2 and 9 for $48 \mathrm{~h}$ and was not affected when stored for 42 days at $-20^{\circ} \mathrm{C}$. These properties were reported for mundticin KS [40] and enterocin QU2 [41] produced by E. mundtii, and the bacteriocins produced by E. faecium JCM $5804^{\mathrm{T}}$ [54] and GM-1 [48]. Therefore, enterocin CRL 1826 could be classified into Class II bacteriocins: heat stable peptides with antilisteria activity [10].

The MIC and MBC of enterocin CRL 1826 were 2,640 and 5,280 $\mathrm{AU} / \mathrm{mL}$, respectively by using $L$. monocytogenes and the addition of $120,000 \mathrm{AU} / \mathrm{mL}$ enterocin CRL 1826 on food-borne growing cells showed bactericidal effect which was switched to bacteriostatic when enterocin-containing supernatants were previously treated with trypsin. However, the released-peptides from enterocin showed bactericidal effect on Gram-negatives from raniculture which must be identified once enterocin CRL 1826 is purified. Saavedra et al. [55] reported that derived-peptides from the C-terminal domain diminished the enterocin CRL 35 activity; while those from middle $\mathrm{N}$-terminal domain improved it when used combined. However, none of them showed activity individually. Later, Salvucci et al. [37] demonstrated the inhibitory activity of $\mathrm{N}$-terminal released peptides from mesentericin Y105, pediocin PA-1, sakasin P, piscicolin 126 and listeriocin 743A.

Enterocin produced cell envelope damages and efflux of cell material on L. monocytogenes. This effect was reported by purified enterocin E1A, a bacteriocin produced by Streptococcus faecium E1 on a L. monocytogenes strain [56]. With respect to enterocin-derived peptides, they produced granulation and contraction of cytoplasm material on $P$. aeruginosa and increase in the periplasmic space and empty cells appearance on $C$. freundii. It represents the first report regarding the mode of action of bacteriocin derived-peptides on Gram negatives, since it has only been previously reported for plantaricin MG on Salmonella Typhimurium [57], EDTA plus bacteriocin-like substance produced by Bacillus sp. P34 on Escherichia coli and S. Typhimurium [58] and lipase plus enterocin on other E. coli and $S$. Typhimurium strains [59].

Listeriosis is one the main diseases associated with industrial food processing; therefore it is placed in the high social and economic relevance diseases [60]. L. monocytogenes is a normal inhabitant of amphibian species including L. catesbeianus [17], thus bullfrog legs may not meet appropriate microbiological standards by virtue of methods of collection and preparation, and then cross-contaminations are of main concern. These products are intended for the direct use of the final consumer; therefore decontamination with enterocin CRL 1826 would increase meat safety.

To maintain the organoleptic characteristics and nutritional properties of food during conservation, the use of bacteriocinogenic LAB strains offers potential alternative applications to diminish the utilization of chemicals preservatives and intensity of heat treatments. Therefore, Nisaplin and Alta 2341 are used as food additives [10].

Taken into account that E. gallinarum CRL 1826 is not appropriated to be included in a multi-strain probitiotic for raniculture, enterocin CRL 1826 would represent an interesting bioactive compound to be combined with probiotics to control/prevent the RLS outbreaks. The use of nisin in aquaculture products has been reported to control botulism in fish vacuum packed and L. monocytogenes in smoked salmon and crab meat [61]. Bacteriocins can be added as concentrated preparations to preserve food, as additives or ingredients to extend the shelf life, or they can be produced in situ by starters, adjunct or protective cultures [62]. Therefore, enterocin CRL 1826 would be used as a biopreservative since it was stable in a range of $\mathrm{pH}$ and temperatures and able to inhibit L. monocytogenes after $1 \mathrm{~h}$ co-incubation.

Finally, the enterocin derived-peptide represents veterinary/ pharmaceutical alternatives to control multidrug-resistant Gramnegatives such as $P$. aeruginosa and C. freundii [63].

\section{Acknowledgments}

This research was supported by grants from Consejo Nacional de Investigaciones Científicas y Técnicas (PIP 744), Agencia Nacional de Promoción Científica y Tecnológica (PICT 1187) and Consejo de Investigaciones de la Universidad Nacional de Tucumán (26/D 414 and PIUNT 528).

\section{References}

1. Verschuere L, Rombaut G, Sorgeloos P, Verstraete W (2000) Probiotic bacteria as biological control agents in aquaculture. Microbiol Mol Biol Rev 64: 655-671.

2. Balcázar JL, de Blas I, Ruiz-Zarzuela I, Vendrell D, Calvo AC, et al. (2007) Changes in intestinal microbiota and humoral immune response following probiotic administration in brown trout (Salmo trutta). Br J Nutr 97: 522-527.

3. Ringø E, Løvmo L, Kristiansen M, Bakke Y, Salinas I, et al. (2010) Lactic acid bacteria vs. pathogens in the gastrointestinal tract of fish. Aquac Res 41: 451-467.

4. Pasteris SE, Roig Babot G, Otero MC, Bühler MI, Nader-Macías ME (2009) Beneficial properties of lactic acid bacteria isolated from a Rana catesbeiana hatchery. Aquac Res 40: 1605-1615.

5. Pasteris SE, Vera Pingitore E, Roig Babot G, Otero MC, Bühler MI, et al. (2009) Characterization of the beneficial properties of lactobacilli isolated from bullfrog (Rana catesbeiana) hatchery. Antonie Van Leeuwenhoek 95: 373-385.

6. Mendoza GM, Pasteris SE, Ale CE, Otero MC, Bühler MI, et al. (2012) Cultivable microbiota of Lithobates catesbeianus and advances in the selection of lactic acid bacteria as biological control agents in raniculture. Res Vet Sci 93: 1160-1167.

7. Reid G, Sanders ME, Gaskins HR, Gibson GR, Mercenier A, et al. (2003) New scientific paradigms for probiotics and prebiotics. J Clin Gastroenterol 37: 105118.

8. Loh TC, Choe DW, Foo HL, Sazili AQ, Bejo MH (2014) Effects of feeding different postbiotic metabolite combinations produced by Lactobacillus plantarum strains on egg quality and production performance, faecal parameters and plasma cholesterol in laying hens. BMC Vet Res 10: 149

9. Cui Y, Zhang C, Wang Y, Shi J, Zhang L, et al. (2012) Class Ila bacteriocins: diversity and new developments. Int J Mol Sci 13: 16668-16707.

10. Cotter PD, Hill C, Ross RP (2005) Bacteriocins: developing innate immunity for food. Nat Rev Microbiol 3: 777-788.

11. EFSA (2006) Opinion of the scientific panel on food additives, flavourings, processing aids and materials in contact with food (AFC) related to the use of nisin (E 234) as a food additive.

12. Hagiwara A, Imai N, Nakashima H, Toda Y, Kawabe M, et al. (2010) A 90-day oral toxicity study of nisin $\mathrm{A}$, an anti-microbial peptide derived from Lactococcus lactis subsp. lactis, in F344 rats. Food Chem Toxicol 48: 2421-2428.

13. Mehta R, Arya R, Goyal K, Singh M, Sharma AK1 (2013) Bio-preservative and therapeutic potential of pediocin: recent trends and future perspectives. Recent Pat Biotechnol 7: 172-178.

14. Oshima S, Hirano A, Kamikado H, Nishimura J, Kawai Y, et al. (2014) Nisin A extends the shelf life of high-fat chilled dairy dessert, a milk-based pudding. J Appl Microbiol 116: 1218-1228.

15. Ishibashi N, Himeno K, Fujita K, Masuda Y, Perez RH, et al. (2012) Purification and characterization of multiple bacteriocins and an inducing peptide produced by Enterococcus faecium NKR-5-3 from Thai fermented fish. Biosci Biotechnol Biochem 76: 947-953. 
Citation: Montel Mendoza G, Ale CE, Nader-Macías MEF, Pasteris SE (2015) Characterization of a Bacteriocin Produced by Enterococcus gallinarum CRL 1826 Isolated from Captive Bullfrog: Evaluation of its Mode of Action against Listeria monocytogenes and Gram-Negatives. J Bioprocess Biotech 5: 250 doi:10.4172/2155-9821.1000250

16. Pagadala S, Parveen S, Rippen T, Luchansky JB, Call JE, et al. (2012) Prevalence, characterization and sources of Listeria monocytogenes in blue crab (Callinectus sapidus) meat and blue crab processing plants. Food Microbiol 31: 263-270.

17. Botzler RG, Wetzler TF, Cowan AB (1973) Listeria in aquatic animals. J Wild Dis 9: $163-170$.

18. Jofré A, Garriga M, Aymerich T (2007) Inhibition of Listeria monocytogenes in cooked ham through active packaging with natural antimicrobials and highpressure processing. J Food Prot 70: 2498-2502.

19. Renye JA Jr, Somkuti GA, Paul M, Van Hekken DL (2009) Characterization of antilisterial bacteriocins produced by Enterococcus faecium and Enterococcus durans isolates from Hispanic-style cheeses. J Ind Microbiol Biotechnol 36: 261-268.

20. Valenzuela AS, Benomar N, Abriouel H, Cañamero MM, Gálvez A (2010) Isolation and identification of Enterococcus faecium from seafoods: antimicrobial resistance and production of bacteriocin-like substances. Food Microbiol 27: 955-961.

21. Moraes PM, Perin LM, Todorov SD, Silva A Jr, Franco BD, et al. (2012) Bacteriocinogenic and virulence potential of Enterococcus isolates obtained from raw milk and cheese. J Appl Microbiol 113: 318-328.

22. Chen YS, Yu CR, Ji SH, Liou MS, Leong KH, et al. (2013) Enterocin T, a novel class Ila bacteriocin produced by Enterococcus sp. 812. Arch Microbiol 195 $655-660$.

23. Migaw S, Ghrairi T, Belguesmia Y, Choiset Y, Berjeaud JM, et al. (2014) Diversity of bacteriocinogenic lactic acid bacteria isolated from Mediterranean fish viscera. World J Microbiol Biotechnol 30: 1207-1217.

24. Khan H, Flint S, Yu PL (2010) Enterocins in food preservation. Int J Food Microbiol 141: 1-10.

25. Pogány Simonová M, Lauková A, Haviarová M (2010) Pseudomonads from rabbits and their sensitivity to antibiotics and natural antimicrobials. Res Vet Sci 88: 203-207.

26. Gaaloul N, ben Braiek O, Hani K, Volski A, Chikindas ML, et al. (2015) Isolation and characterization of large spectrum and multiple bacteriocin-producing Enterococcus faecium strain from raw bovine milk. J Appl Microbiol 118: 343-355.

27. Pasteris SE, Bühler MI, Nader-Macías ME (2006) Microbiological and histological studies of farmed-bullfrog (Rana catesbeiana) tissues displaying red-leg syndrome. Aquaculture 251: 11-18.

28. Ogier JC, Serror $P$ (2008) Safety assessment of dairy microorganisms: the Enterococcus genus. Int J Food Microbiol 126: 291-301.

29. López M, Sáenz Y, Rojo-Bezares B, Martínez S, del Campo R, et al. (2009) Detection of vanA and vanB2-containing enterococci from food samples in Spain, including Enterococcus faecium strains of CC17 and the new singleton ST425. Int J Food Microbiol 133: 172-178

30. De Man JC, Rogosa M, Sharpe E (1969) A medium for cultivation of lactobacilli. J Appl Bacteriol 23: 130-145.

31. Raibaud P, Gapin JV, Ducluzeau R, Mocquot G, Oliver G (1963) Le genre Lactobacillus dans le tube digestif du Rat. II Caractères de souches hétérofermentaires isolées de rats "Holo" et "Gnotoxeniques". Ann Microbio 124(2): 223-235

32. Pasteris SE, Vera Pingitore E, Ale CE, Nader-Macías ME (2014) Characterization of a bacteriocin produced by Lactococcus lactis subsp. lactis CRL 1584 isolated from a Lithobates catesbeianus hatchery. World J Microbio Biotechnol 30: 1053-1062.

33. Clinical and Laboratory Standards Institute (2006) Methods for antimicrobia dilution and disk susceptibility testing of infrequently isolated or fastidious bacteria; Approved Guideline. CLSI document M45-A. Clinical and Laboratory Standards Institute, Wayne, Pennsylvania, USA

34. Clinical and Laboratory Standards Institute (1999) Methods for determining bactericidal activity of antimicrobial agents; Approved Guideline. CLSI document M26-A. Clinical and Laboratory Standards Institute, Wayne, Pennsylvania, USA.

35. Pasteris SE, Guidoli MG, Otero MC, Bühler MI, Nader-Macías ME (2011) In vitro inhibition of Citrobacter freundii, a red-leg syndrome associated pathogen in raniculture, by indigenous Lactococcus lactis CRL 1584. Vet Microbiol 151 336-344.
36. Almeida T, Brandão A, Muñoz-Atienza E, Gonçalves A, Torres C, et al. (2011) Identification of bacteriocin genes in enterococci isolated from game animals and saltwater fish. J Food Prot 74: 1252-1260.

37. Salvucci E, Saavedra L, Hebert EM, Haro C, Sesma F (2012) Enterocin CRL35 inhibits Listeria monocytogenes in a murine model. Foodborne Pathog Dis 9 . 68-74.

38. Nes IF, Yoon SS, Diep DB (2007) Ribosomally synthesized antimicrobia peptides (bacteriocins) in lactic acid bacteria: a review. Food Sci Biotechnol 16: $675-690$

39. Fisher K, Phillips C (2009) The ecology, epidemiology and virulence of Enterococcus. Microbiology 155: 1749-1757

40. Kawamoto S, Shima J, Sato R, Eguchi T, Ohmomo S, et al. (2002) Biochemica and genetic characterization of mundticin KS, an antilisterial peptide produced by Enterococcus mundtii NFRI 7393. Appl Environ Microbiol 68: 3830-3840.

41. Zendo T, Eungruttanagorn N, Fujioka S, Tashiro Y, Nomura K, et al. (2005) Identification and production of a bacteriocin from Enterococcus mundtii QU 2 isolated from soybean. J Appl Microbiol 99: 1181-1190.

42. Ferreira AE, Canal N, Morales D, Bopp Fuentefria D, Corção G (2007) Characterization of enterocins produced by Enterococcus mundtii isolated from humans feces. Braz Arch Biol Technol 50: 249-258.

43. Sabia C, Messi P, de Niederhäusern S, Manicardi G, Bondi M (2004) Study of two bacteriocins produced by Enterococcus casseliflavus and Enterococcus faecalis. Lett Appl Microbiol 38: 99-105

44. Sánchez J, Diep DB, Herranz C, Nes IF, Cintas LM, et al. (2007) Amino acid and nucleotide sequence, adjacent genes, and heterologous expression of hiracin JM79, a sec-dependent bacteriocin produced by Enterococcus hirae DCH5, isolated from Mallard ducks (Anas platyrhynchos). FEMS Microbiol Lett 270: $227-236$.

45. Birri DJ, Brede DA, Forberg T, Holo H, Nes IF (2010) Molecular and genetic characterization of a novel bacteriocin locus in Enterococcus avium isolates from infants. Appl Environ Microbiol 76: 483-492.

46. Jennes W, Dicks LMT, Verwoerd DJ (2000) Enterocin 012, a bacteriocin produced by Enterococcus gallinarum isolated from the intestinal tract of ostrich. J Appl Microbiol 88: 349-357.

47. Lauková A, Juris P, Vasilková Z, Papajová I (2000) Treatment of sanitaryimportant bacteria by bacteriocin substance V24 in cattle dung water. Lett Appl Microbiol 30: 402-405.

48. Kang JH, Lee MS (2005) Characterization of a bacteriocin produced by Enterococcus faecium GM-1 isolated from an infant. J Appl Microbiol 98: 11691176.

49. De Kwaadsteniet M, Todorov SD, Knoetze H, Dicks LM (2005) Characterization of a $3944 \mathrm{Da}$ bacteriocin, produced by Enterococcus mundtii ST15, with activity against Gram-positive and Gram-negative bacteria. Int J Food Microbiol 105 433-444.

50. Liu W, Zhang L, Yi H, Shi J, Xue C, et al. (2014) Qualitative detection of class Ila bacteriocinogenic lactic acid bacteria from traditional Chinese fermented food using a YGNGV-motif-based assay. J Microbiol Methods 100: 121-127.

51. Franz CM, Schillinger U, Holzapfel WH (1996) Production and characterization of enterocin 900, a bacteriocin produced by Enterococcus faecium BFE 900 from black olives. Int J Food Microbiol 29: 255-270.

52. Mareková M, Lauková A, DeVuyst L, Skaugen M, Nes IF (2003) Partial characterization of bacteriocins produced by environmental strain Enterococcus faecium EK13. J Appl Microbiol 94: 523-530.

53. Annamalai N, Manivasagan P, Balasubramanian T, Vijayalakshmi S (2009) Enterocin from Enterococcus faecium isolated from mangrove environment. Afr J Biotechnol 8: 6311-6316.

54. Park SH, Itoh K, Fujisawa T (2003) Characteristics and identification of enterocins produced by Enterococcus faecium JCM 5804T. J Appl Microbiol 95: 294-300.

55. Saavedra L, Minahk C, de Ruiz Holgado AP, Sesma F (2004) Enhancement of the enterocin CRL35 activity by a synthetic peptide derived from the $\mathrm{NH} 2$ terminal sequence. Antimicrob Agents Chemother 48: 2778-2781.

56. Krämer J, Lenz W, Viebahn A, Brandis H (1977) Electronenmicroscopic studies on cells of Listeria monocytogenes treated with enterocin (author's transl). Zentralbl Bakteriol Orig A 237: 318-323. 
Citation: Montel Mendoza G, Ale CE, Nader-Macías MEF, Pasteris SE (2015) Characterization of a Bacteriocin Produced by Enterococcus gallinarum CRL 1826 Isolated from Captive Bullfrog: Evaluation of its Mode of Action against Listeria monocytogenes and Gram-Negatives. J Bioprocess Biotech 5: 250 doi:10.4172/2155-9821.1000250

Page 9 of 9

57. Gong HS, Meng XC, Wang H (2010) Mode of action of plantaricin MG, a bacteriocin active against Salmonella typhimurium. J Basic Microbiol 50 Suppl 1: $\$ 37-45$

58. Motta AS, Flores FS, Souto AA, Brandelli A (2008) Antibacterial activity of a bacteriocin-like substance produced by Bacillus sp. P34 that targets the bacterial cell envelope. Antonie Van Leeuwenhoek 93: 275-284

59. Ramakrishnan V, Narayan B, Halami PM (2012) Combined effect of enterocin and lipase from Enterococcus faecium NCIM5363 against food borne pathogens: mode of action studies. Curr Microbiol 65: 162-169.

60. FAO/OMS (2004) Risk assessment of Listeria monocytogenes in ready-to-eat foods. In: microbiological risk assessment series 5 , technical report. Rome, Italy
61. Delves-Broughton J (2005) Nisin as a food preservative. Food Australia 57: 525-527.

62. Gálvez A, Abriouel H, López RL, Ben Omar N (2007) Bacteriocin-based strategies for food biopreservation. Int J Food Microbiol 120: 51-70.

63. Bendjeddou K, Fons M, Strocker P, Sadoun D (2012) Characterization and purification of a bacteriocin from Lactobacillus paracasei subsp. paracasei BMK2005, an intestinal isolate active against multidrug-resistant pathogens. World J Microbiol Biotechnol 28: 1543-1552. 